\title{
Characterization of HSP70 and its expression in tissue: correlation with physiological and immune indices in goose (Anser cygnoides)
} serum

\author{
W.W. Zhang ${ }^{1,2 *}$, X. Xiao ${ }^{2 *}$, J.K. Gan ${ }^{2}$, X.Q. Zhang ${ }^{1,2}$, L.N. Kong ${ }^{1,2}$ and Q.B. Luo ${ }^{1,2}$ \\ 1'Department of Animal Genetics, Breeding and Reproduction, \\ College of Animal Science, South China Agricultural University, Guangzhou, \\ Guangdong, China \\ ${ }^{2}$ Guangdong Provincial Key Lab of Agro-Animal Genomics and Molecular Breeding, \\ Guangzhou, Guangdong, China \\ *These authors contributed equally to this study. \\ Corresponding author: Q.B. Luo \\ E-mail: qbluo@scau.edu.cn
}

Genet. Mol. Res. 14 (4): 12288-12298 (2015)

Received March 6, 2015

Accepted July 1, 2015

Published October 9, 2015

DOI http://dx.doi.org/10.4238/2015.October.9.17

ABSTRACT. We cloned the goose heat shock protein 70 gene (HSP70), to
determine its sequence variation and elucidate its mRNA expression. We
designed primers to amplify the entire goose HSP70 sequence. We used
10 commercial Wuzong goslings in a heat-stress experiment. We collected
tissue samples for RNA extraction and quantitative real-time polymerase
chain reaction (qRT-PCR). We analyzed the variation in expression of goose
HSP70 before and after heat stress. We constructed a DNA pool from six
different species, for single nucleotide polymorphism (SNP) screening. We
detected 18 SNPs and selected three of these SNPs for correlation analysis
with biological and immune traits in 200 Wuzong geese. We showed that
T+237C was significantly correlated with the serum corticosterone level,
whereas T+1122C was significantly correlated with the heterophil to 
lymphocyte ratio. Goose HSP70 contained no introns. The results of qRT$\mathrm{PCR}$ analysis revealed significant gender differences in the expression of goose $\mathrm{HSP} 70$ at $40^{\circ} \mathrm{C}$ but not at $25^{\circ} \mathrm{C}$; moreover, in general, expression was significantly higher at $40^{\circ} \mathrm{C}$ than at $25^{\circ} \mathrm{C}$. With the exception of the leg muscle and cerebellum, HSP70 expression was significantly higher in male geese than in female geese. Our results indicate that goose HSP70 plays an important role in response to severe heat stress.

Key words: Goose; HSP70 gene; Polymorphism; Heat stress

\section{INTRODUCTION}

Environmental temperature has important effects on the performance of poultry (Chen et al., 2004). Heat-shock response is caused by high temperature and causes cryptorrhea, loss of appetite, slow growth, reduced immunity, and disease resistance, thereby leading to increased morbidity and mortality (Mahmoud et al., 1996; Christensen et al., 2000; Zerjal et al., 2013). Heat shock protein (HSP) is induced by high environmental temperature and is important for the maintenance of a stable internal environment for intracellular proteins (Lindquist and Craig, 1988). HSP assists in protein transshipment and damage repair under heat stress, thereby maintaining the integrity of cells (Hendrick and Hartl, 1993). HSPs have been extensively investigated; however, most studies have focused on mammals and chickens, and data regarding other poultry species are lacking. At high temperatures, heat resistance and autoregulation are higher in geese than in mammals (Ajloo et al., 2002). The heat shock protein 70 gene (HSP70) is the most widely studied member of the HSP family. Beckham et al. (2008) reported that lack of HSP70 led to a marked decrease in the heat resistance of cells. Miyabara et al. (2012) showed that in rats suffering from disuse atrophy of skeletal muscle, overexpression of HSP70 contributed to recovery of the structure and function of skeletal muscle. A few studies have investigated correlations between polymorphism and HSP70 function in mammals and chickens. Rosenkrans et al. (2010) found that the promoter region of bovine HSP70 is polymorphic and it may be associated with fertility. Zhen et al. (2006) demonstrated that different genotypes at polymorphism sites (C+276G and $A+258 G)$ were correlated with HSP70 mRNA expression in the liver and leg muscle, and that mRNA expression of heterozygous HSP70 was significantly higher than that of other genotypes. However, to the best of our knowledge, no previous structural and functional studies of goose HSP70 have been conducted. In the present study, we investigated the structure of goose HSP70 and examined its molecular characteristics.

\section{MATERIAL AND METHODS}

\section{Sample collection}

We obtained 20 commercial goslings (10 male and 10 female) of Wuzong geese (WZG) from Zhiteqi Goose Industry Co. Ltd., Yangjiang City, Guangdong, China. The goslings were raised to 7 days according to Martin et al. (1998). All the goslings were transferred to two manual climatic boxes for $30 \mathrm{~min}$. Next, 10 goslings ( 5 male and 5 female) were subjected to $1 \mathrm{~h}$ of continuous heat stress at $40^{\circ} \mathrm{C}$ and $>70 \%$ humidity (treatment group). The remaining 10 goslings (5 male and 5 female) were maintained at $25^{\circ} \mathrm{C}$ (control group). At the end of the experiment, the goslings 
were killed by cervical dislocation. The liver, kidneys, ovaries, testes, spleen, pituitarium, muscular stomach, glandular stomach, lung, uropygial gland, pectoral muscle, leg muscle, hypothalamus, cerebrum, cerebellum, and heart were collected and used in HSP70 tissue differential expression analysis. After acquisition, samples were immediately stored in liquid nitrogen. All procedures were conducted according to protocols approved by the Committee for the Care and Use of Experimental Animals at South China Agricultural University, Guangzhou, Guangdong, China.

\section{Measurement of serum corticosterone level and heterophil to lymphocyte ratio}

We obtained 200 commercial 30-week-old WZG individuals from Zhiteqi Goose Industry Co. Ltd., Yangjiang City, Guangdong, China. We collected blood samples $(400 \mu \mathrm{L})$ from the wing veins of these geese. We randomly repackaged the obtained blood samples into four different blood collection tubes. We subsequently used the plasma samples for genomic DNA isolation using phenol-chloroform extraction formulation and for index determination of thermotolerance traits. We detected serum corticosterone using an enzyme linked immuno-sorbent assay (Darui Antibody Limited, Guangzhou, Guangdong, China) according to the manufacturer protocol. The heterophil to lymphocyte ratio $(\mathrm{H} / \mathrm{L})$ was measured by the People's Liberation Army Hospital 458 (Guangzhou, Guangdong, China).

\section{DNA and RNA isolation and RNA reverse transcription}

Genomic DNA of the 20 goslings and 200 WZG was extracted from anticoagulant blood using a standard phenol-chloroform method. Total RNA of the 20 goslings was extracted using an RNA isolation kit (Tiangen, Guangzhou, Guangdong, China) and was purified using DNA Erasol (Tiangen). The RNA was reverse transcribed with a ReverTra Ace- $\alpha^{\text {TM }}$ kit (TaKaRa Biotechnology Co., Ltd. Dalian, Liaoning, China). All procedures followed manufacturer protocols.

\section{Polymerase chain reaction, rapid amplification of cDNA ends, and genome walking}

We used the chicken HSP70 sequence (GenBank accession No. AY143693) as a template to design primers $A, B$, and $C$ (Table 1). The polymerase chain reaction (PCR) mixture contained $1 \mu \mathrm{L} 1 \mathrm{mM}$ goose cDNA, $1 \mu \mathrm{L} 10 \mathrm{mM}$ of each forward and reverse primers, $8 \mu \mathrm{L} 2.5 \mathrm{mM}$ dNTPs, $4.5 \mu \mathrm{L}$ 10X LA Polymerase Chain Reaction Buffer II (TaKaRa), $0.5 \mu \mathrm{L} 25 \mathrm{mM} \mathrm{MgCl}, 5 \mathrm{U} / \mu \mathrm{L} \mathrm{LA}$

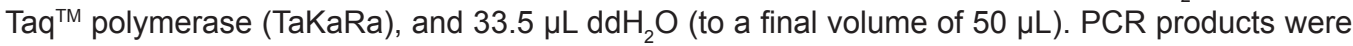
detected using electrophoresis in $2 \%$ agarose gel containing ethidium bromide.

Rapid amplification of cDNA ends (3'RACE) (TaKaRa) was used to generate the first strand. Two nesting primers $-3 \mathrm{SP} 2 \mathrm{~F}$ and 3SP3F- were designed according to the goose HSP70 sequence (Table 1). The reaction process included denaturation at $94^{\circ} \mathrm{C}$ for $3 \mathrm{~min}$; followed by 30 cycles each at $94^{\circ} \mathrm{C}$ for $30 \mathrm{~s}, 65^{\circ} \mathrm{C}$ for $30 \mathrm{~s}$, and $72^{\circ} \mathrm{C}$ for $1 \mathrm{~min}$; and a final elongation step of $72^{\circ} \mathrm{C}$ for $10 \mathrm{~min}$.

We amplified untranslated regions (5'UTR) using a Genome Walking kit (TaKaRa). We used the goose HSP70 sequence (GenBank accession No. EU680475) as a template to design primers SP1R, SP2R, and SP3R (Table 1). The reaction process included denaturation at $94^{\circ} \mathrm{C}$ for $1 \mathrm{~min}$ and $98^{\circ} \mathrm{C}$ for $1 \mathrm{~min}$; followed by five cycles each at $94^{\circ} \mathrm{C}$ for $30 \mathrm{~s}, 65^{\circ} \mathrm{C}$ for $1 \mathrm{~min}$, and $72^{\circ} \mathrm{C}$ for $2 \mathrm{~min} ; 15$ cycles each at $94^{\circ} \mathrm{C}$ for $30 \mathrm{~s}, 65^{\circ} \mathrm{C}$ for $1 \mathrm{~min}, 72^{\circ} \mathrm{C}$ for $2 \mathrm{~min}, 94^{\circ} \mathrm{C}$ for $30 \mathrm{~s}, 65^{\circ} \mathrm{C}$ for $1 \mathrm{~min}, 72^{\circ} \mathrm{C}$ for $2 \mathrm{~min}, 94^{\circ} \mathrm{C}$ for $30 \mathrm{~s}, 44^{\circ} \mathrm{C}$ for $1 \mathrm{~min}$, and $72^{\circ} \mathrm{C}$ for $2 \mathrm{~min}$; and a final elongation step of $72^{\circ} \mathrm{C}$ for $10 \mathrm{~min}$. We designed the primers SP4R, SP5R, and SP6R (Table 1) according to 
the results of the final step. The reaction process used to design the primers was the same as that of the final step. All procedures followed manufacturer protocols. We used the genome walking sequence as a template to design verification primer $D$ (Table 1). We used goose genomic DNA and CDNA as templates for PCR amplification and expanded product sequencing.

\section{Quantitative real-time PCR}

We analyzed the expression levels of goose HSP70 in different tissues before and after heat treatment using quantitative real-time PCR (qRT-PCR) with the SYBR Green Real-Time PCR Master Mix (Toyobo, Japan). The qRT-PCR reactions were performed in a final volume of $20 \mu \mathrm{L}$ according to the manufacturer protocol. The expression level was determined by comparing the HSP70 mRNA level with the $\beta$-actin level. Primer E was used. For each sample, PCR was conducted in triplicate using an ABI7500 Real-Time PCR system (Applied Biosystems, Foster City, USA). The amplification efficiencies of the target $H S P 70$ and reference $\beta$-actin mRNA sequences were approximately equal. The HSP70 mRNA levels in all samples were normalized using the following formula:

$$
\text { Relative quantity of } H S P 70 \mathrm{mRNA}=2^{-\Delta \Delta \mathrm{Ct}}
$$

where $\Delta \Delta C t$ corresponds to the difference between the $\Delta C t$ measured for the mRNA level of each tissue. Here:

$$
\Delta \mathrm{Ct}=\mathrm{Ct}_{H S P 70}-\mathrm{Ct}_{\beta-\text { actin }}
$$

If the difference in $\mathrm{Ct}$ values was $>0.04$, the two reactions were repeated.

\section{Single nucleotide polymorphism (SNP) screening and genotyping}

We randomly selected DNA of 10 individuals from each of six breeds of goose - WZG, Magang Goose, Lion Head Goose, Sichuan White Goose, Landaise Goose, and Yellow-Mane Goose. We used the 60 samples obtained to construct a DNA pool. The DNA pool was prepared by mixing equal amounts (final concentration $=0.02 \mu \mathrm{g} / \mu \mathrm{L}$ ) of DNA from each bird. We used four pairs of primers - G1, G2, G3, and G4 (Table 1) - for PCR amplification; the products were sent for direct sequencing(G1, G2, G3, and G4) and polymorphisms of the HSP70 were identified. Genotyping of SNP was performed using polymerase chain reaction-restriction fragment length polymorphism (PCR-RFLP) on genomic DNA from 200 WZG, with two pairs of primers - $\mathrm{H} 1$ and $\mathrm{H} 2$ (Table 1). The PCR-RFLP process was as follows: Csp6l, HpyCH4III/Taal, and Acil restriction enzymes (TaKaRa) were tested for genotyping; $10 \mu \mathrm{L}$ amplified PCR products were digested using the manufacturer protocols; the DNA fragments were analyzed using electrophoresis in $2 \%$ agarose gel for $20 \mathrm{~min}$ at $120 \mathrm{~V}$; the electrophoresis gel was stained in $0.5 \mathrm{X}$ TBE buffer containing $0.5 \mu \mathrm{g} / \mathrm{mL}$ ethidium bromide; and the DNA bands were observed and photographed under UV illumination.

\section{Statistical analysis}

We conducted statistical analyses using SAS version 9.0 (SAS Institute Inc., Cary, NC, 
USA). We used $t$-tests to test for significant differences. Differences were considered significant at $P<0.05$. Data are reported as means \pm SE.

\section{RESULTS}

\section{Goose HSP70 sequence}

We obtained three PCR products of 1715, 435 bp (including a 434-bp 3'UTR obtained using 3'RACE), and 359 bp (a 206-bp product obtained using genome walking included a 97-bp 5'UTR) with primers A, B, and C, respectively. Sequence splicing produced a 2436-bp sequence [subsequently uploaded to the National Center of Biotechnology Information (NCBI) GenBank database (GenBank accession No. EU680475)], which included a 1905-bp open reading frame (ORF), a 97-bp 5'UTR, and a 434-bp 3'UTR. We obtained identical 2103-bp products using PCR amplifications of genomic DNA and CDNA with primer $F$.

\begin{tabular}{|c|c|c|c|c|}
\hline Primer name & & $5^{\prime} \rightarrow 3^{\prime}$ & Product (bp) & Annealing temperature $\left({ }^{\circ} \mathrm{C}\right)$ \\
\hline \multirow[t]{2}{*}{ A } & $\mathrm{F}$ & CCCCACAGTGCAGTCAGAC & 1715 & 61.5 \\
\hline & $\mathrm{R}$ & CGTGCCTTCCCTTTTATCA & & \\
\hline $3 S P 2 F$ & & TTGACAAGTGCCGGGAGGTGATCT & 447 & 65 \\
\hline 3SP3F & & GAAACTCTGCAACCCGATCGTCAC & & \\
\hline \multirow[t]{2}{*}{ B } & $\mathrm{F}$ & GTGGTGAATGATGCTGGCAGAC & 435 & 61 \\
\hline & $\mathrm{R}$ & GCGGTTGTCAAAGTCCTCCC & & \\
\hline \multirow[t]{2}{*}{ C } & $\mathrm{F}$ & GGACCACGCCGAGCTATGT & 359 & 61 \\
\hline & $\mathrm{R}$ & GCGCTGGGAGTCATTGAAGT & & \\
\hline SP1R & & CTCAAAGCGGGCACGAGTAATG & & \\
\hline SP2R & & ATGCGGTTGTCAAAGTCCTCCCC & & \\
\hline SP3R & & GCTGCTGTGGGCTCGTTGATAAT & & \\
\hline SP4R & & TAGGCCTCGGCAATCTCCTTC & & \\
\hline SP5R & & CACCGTGGGGTCATCGTACTT & & \\
\hline SP6R & & TTGCCATGCTGGAAGACGCC & & \\
\hline \multirow[t]{2}{*}{$\mathrm{D}$} & $\mathrm{F}$ & CTGCAACGGCAGAACGTG & 492 & 55 \\
\hline & $\mathrm{R}$ & GCCTCGGCAATCTCCTTC & & \\
\hline \multirow[t]{2}{*}{$\mathrm{E}$} & $\mathrm{F}$ & GTACTCATGCGTGGGCGT & 207 & 52 \\
\hline & $\mathrm{R}$ & CACCGTGGGGTCATCGTA & & \\
\hline \multirow[t]{2}{*}{$\mathrm{F}$} & $\mathrm{F}$ & CCCCACAGTGCAGTCAGAC & 2103 & 62 \\
\hline & $\mathrm{R}$ & GCCTCGGCAATCTCCTTC & & \\
\hline \multirow[t]{2}{*}{ G1 } & $\mathrm{F}$ & CTTCACCGATACTGAGCG3 & 582 & 55 \\
\hline & $\mathrm{R}$ & GTTGTCAAAGTCСTCСCC & & \\
\hline \multirow[t]{2}{*}{ G2 } & $\mathrm{F}$ & CTGGGGGGGGAGGACTTT & 349 & 53 \\
\hline & $\mathrm{R}$ & GGGATACGGGTGGAGCCT & & \\
\hline \multirow[t]{2}{*}{ G3 } & $\mathrm{F}$ & CCAAAAACTACTACAGGA & 643 & 53 \\
\hline & $\mathrm{R}$ & TTCССTTCAGTTTATCAT & & \\
\hline \multirow[t]{2}{*}{ G4 } & $\mathrm{F}$ & GAGGATGATAAACTGAAG & 497 & 54 \\
\hline & $\mathrm{R}$ & TTACTTTAGAAGAGACAC & & \\
\hline \multirow[t]{2}{*}{$\mathrm{H} 1$} & $\mathrm{~F}$ & GTGGGCGTCTTCCAGCAT & 343 & 53 \\
\hline & $\mathrm{R}$ & TCGGCAATCTCCTTCATCTT & & \\
\hline \multirow[t]{2}{*}{$\mathrm{H} 2$} & $\mathrm{~F}$ & GAGATCGTGCTGGTTGGA & 402 & 55 \\
\hline & $\mathrm{R}$ & CTGGAGGGATGCCTGTTA & & \\
\hline \multirow[t]{2}{*}{$\beta$-actin } & $\mathrm{F}$ & СТСССССАTGССАTССТССGTСTG & 150 & 52 \\
\hline & $\mathrm{R}$ & GCTGTGGCСАTСTССTGCTC & & \\
\hline
\end{tabular}

Primers were used as follows: A, for partial goose HSP70 coding region amplification; 3SP2F and 3SP3F, for 3'RACE; $B$ and $C$, for partial CDNA; SP1R-SP6R, for genome walking; $D$, for verifying whether the gene contained introns; $E$, for qRT-PCR; G1-G4, for SNP screening; $\mathrm{H} 1$ and H2, for PCR-RFLP; $\beta$-actin for internal reference; $F$ for forward primer; $\mathrm{R}$ for reverse primer. 


\section{Polymorphism of goose HSP70 and genotyping}

We identified 18 SNPs (Table 2) within the goose HSP70 ORF and 5'UTR, of which three were transversions and 15 were transitions. Amino acid changes were caused by three SNPs - S5, S8, and S9. We genotyped S3, S11, and S13 using PCR-RFLP with Csp6I, HpyCH4III/Taal, and Acil, respectively.

Table 2. Polymorphism information regarding the goose HSP70 gene.

\begin{tabular}{|c|c|c|c|c|}
\hline Name & Location & Type & Codon & Amino acid \\
\hline S1 & G-16 A & Transition & - & - \\
\hline S2 & $\mathrm{C}+6 \mathrm{~T}$ & Transition & tct-tcc & Ser-Ser \\
\hline S3 & $\mathrm{T}+237 \mathrm{C}$ & Transition & tat-tac & Tyr-Tyr \\
\hline S4 & $A+258 G$ & Transition & tca-tcg & Ser-Ser \\
\hline S5 & $A+475 C$ & Transversion & acc-ccc & Thr-Pro \\
\hline S6 & $\mathrm{C}+483 \mathrm{~T}$ & Transition & gac-gat & Asp-Asp \\
\hline S7 & $\mathrm{C}+516 \mathrm{~T}$ & Transition & cgc-cgt & Arg-Arg \\
\hline S8 & $A+532 C$ & Transversion & aca-cca & Thr-Pro \\
\hline S9 & $A+560 C$ & Transversion & gcc-gac & Ala-Asp \\
\hline S10 & $A+876 G$ & Transition & gaa-gag & Glu-Glu \\
\hline S11 & $\mathrm{T}+1122 \mathrm{C}$ & Transition & tac-tat & Tyr-Tyr \\
\hline S12 & $\mathrm{C}+1146 \mathrm{~T}$ & Transition & atc-att & lle-lle \\
\hline $\mathrm{S} 13$ & $C+1242 T$ & Transition & acc-act & Thr-Thr \\
\hline S14 & $\mathrm{C}+1404 \mathrm{~T}$ & Transition & ccc-cct & Pro-Pro \\
\hline S15 & $\mathrm{C}+1416 \mathrm{~T}$ & Transition & cgc-cgt & Arg-Arg \\
\hline S16 & $A+1479 G$ & Transition & gcg-gca & Ala-Ala \\
\hline S17 & $\mathrm{C}+1887 \mathrm{~T}$ & Transition & act-acc & Thr-Thr \\
\hline S18 & $\mathrm{C}+1890 \mathrm{~T}$ & Transition & atc-att & Ile-Ile \\
\hline
\end{tabular}

\section{Correlation of goose HSP70 with serum corticosterone level and H/L at different temperatures}

We performed association analysis of S3, S11, and S13 of WZG HSP70 with the serum corticosterone level and $\mathrm{H} / \mathrm{L}$ at $25^{\circ}$ and $40^{\circ} \mathrm{C}$ (Tables 3 and 4). At $25^{\circ} \mathrm{C}$, S3 was significantly associated with the serum corticosterone level $(P<0.05)$; moreover, the serum corticosterone level was higher for TC than for the other two genotypes (Table 4). In contrast, S11 was significantly associated with the $H / L(P<0.05)$; moreover, the $H / L$ was lower for $T C$ than for the other two genotypes (Table 4). At $40^{\circ} \mathrm{C}$, none of the three investigated SNPs of WZG HSP70 were correlated with the serum corticosterone level or $\mathrm{H} / \mathrm{L}$ (Table 3 ).

\section{Table 3. Association of S3, S11, and S13 with serum corticosterone level and $\mathrm{H} / \mathrm{L}$ at $40^{\circ} \mathrm{C}$.}

\begin{tabular}{lccc}
\hline Location & Genotype & Corticosterone level $(\mathrm{ng} / \mathrm{mL})$ & $\mathrm{H} / \mathrm{L}$ \\
\hline S3 & TT & $12.85 \pm 8.93(16)$ & $0.37 \pm 0.03(18)$ \\
& TC & $27.65 \pm 4.40(66)$ & $0.37 \pm 0.02(56)$ \\
S11 & CC & $33.53 \pm 3.59(99)$ & $0.39 \pm 0.01(87)$ \\
& TT & $32.94 \pm 3.44(119)$ & $0.38 \pm 0.01(103)$ \\
& TC & $26.66 \pm 6.17(37)$ & $0.39 \pm 0.02(32)$ \\
S13 & CC & $25.86 \pm 9.10(17)$ & $0.36 \pm 0.03(17)$ \\
& TT & $26.75 \pm 8.49(19)$ & $0.38 \pm 0.03(18)$ \\
& TC & $26.64 \pm 5.40(47)$ & $0.39 \pm 0.02(40)$ \\
& CC & $32.49 \pm 3.48(113)$ & $0.38 \pm 0.01(100)$ \\
\hline
\end{tabular}

Individual number of each genotype is shown in parentheses. Data are reported as means \pm SE. 
Table 4. Association of $\mathrm{S} 3, \mathrm{~S} 11$, and $\mathrm{S} 13$ with serum corticosterone level and $\mathrm{H} / \mathrm{L}$ at $25^{\circ} \mathrm{C}$.

\begin{tabular}{lccc}
\hline Location & Genotype & Corticosterone level $(\mathrm{ng} / \mathrm{mL})$ & $\mathrm{H} / \mathrm{L}$ \\
\hline S3 & TT & $11.39 \pm 1.70(14)^{\mathrm{b}}$ & $0.47 \pm 0.05(15)$ \\
& TC & $31.53 \pm 3.78(58)^{\mathrm{a}}$ & $0.41 \pm 0.03(48)$ \\
S11 & CC & $22.35 \pm 3.22(80)^{\mathrm{ab}}$ & $0.45 \pm 0.02(66)$ \\
& TT & $27.24 \pm 3.03(99)$ & $0.49 \pm 0.05(81)^{\mathrm{a}}$ \\
& TC & $27.51 \pm 5.09(35)$ & $0.36 \pm 0.03(31)^{\mathrm{b}}$ \\
S13 & CC & $12.59 \pm 8.05(14)$ & $0.45 \pm 0.02(14)^{\mathrm{a}}$ \\
& TT & $27.53 \pm 7.68(16)$ & $0.47 \pm 0.04(16)$ \\
& TC & $27.60 \pm 4.74(42)$ & $0.39 \pm 0.03(35)$ \\
& CC & $25.07 \pm 3.17(94)$ & $0.47 \pm 0.04(77)$ \\
\hline
\end{tabular}

Different superscript letters within the same column indicate significant differences at $P<0.05$. The individual number of each genotype is shown in parentheses. Data are reported as means $\pm \mathrm{SE}$.

\section{Tissue expression levels of goose HSP70}

The results of qRT-PCR analysis revealed that at $25^{\circ} \mathrm{C}$, the expression level of male goose (MG) HSP70 mRNA was higher in the leg muscle, followed by the hypothalamus, testes, heart, lungs, pectoral muscle, cerebellum, uropygial gland, kidneys, muscular stomach, glandular stomach, pituitarium, cerebrum, liver, and spleen. In contrast, at $40^{\circ} \mathrm{C}$, the expression level was higher in pectoral muscle, followed by the lungs, pituitarium, uropygial gland, testes, kidneys, heart, spleen, hypothalamus, liver, glandular stomach, muscular stomach, cerebrum, cerebellum, and leg muscle. With the exception of the leg muscle, the expression levels of HSP70 mRNA in tissue were significantly higher at $40^{\circ} \mathrm{C}$ than at $25^{\circ} \mathrm{C}$ (Table 5).

Table 5. Differences in expression of $H S P 70$ mRNA in MG tissues at $25^{\circ}$ and $40^{\circ} \mathrm{C}$.

\begin{tabular}{lrrr}
\hline Tissue & \multicolumn{1}{c}{$40^{\circ} \mathrm{C}(5)$} & $25^{\circ} \mathrm{C}(5)$ & $P$ value \\
\hline Liver & $5.84 \pm 0.95$ & $0.02 \pm 0.004$ & $<0.0001$ \\
Kidney & $9.09 \pm 1.59$ & $0.07 \pm 0.01$ & $<0.0001$ \\
Testis & $9.91 \pm 1.32$ & $0.21 \pm 0.03$ & 0.0008 \\
Spleen & $6.36 \pm 0.93$ & $0.02 \pm 0.004$ & $<0.0001$ \\
Pituitarium & $13.34 \pm 1.04$ & $0.06 \pm 0.01$ & $<0.0001$ \\
Muscular stomach & $3.41 \pm 0.49$ & $0.07 \pm 0.02$ & 0.0028 \\
Glandular stomach & $4.51 \pm 0.49$ & $0.07 \pm 0.02$ & $<0.0001$ \\
Lung & $18.50 \pm 4.31$ & $0.16 \pm 0.03$ & $<0.0001$ \\
Uropygial gland & $10.42 \pm 1.05$ & $0.08 \pm 0.02$ & 0.0008 \\
Pectoral muscle & $24.30 \pm 2.85$ & $0.11 \pm 0.01$ & $<0.0001$ \\
Leg muscle & $1.32 \pm 0.29$ & $0.53 \pm 0.14$ & 0.5678 \\
Hypothalamus & $6.22 \pm 0.60$ & $0.31 \pm 0.06$ & 0.0187 \\
Cerebrum & $3.05 \pm 0.14$ & $0.03 \pm 0.006$ & 0.0045 \\
Cerebellum & $2.44 \pm 0.55$ & $0.11 \pm 0.03$ & 0.0043 \\
Heart & $6.48 \pm 0.93$ & $0.18 \pm 0.03$ & 0.0027 \\
\hline
\end{tabular}

Parentheses indicate the number of individuals. Data are reported as means \pm SE.

At $25^{\circ} \mathrm{C}$, the expression level of female goose (FG) HSP70 mRNA was higher in the leg muscle, followed by the lungs, cerebellum, hypothalamus, heart, uropygial gland, pituitarium, cerebrum, pectoral muscle, kidney, ovary, spleen, glandular stomach, liver, and muscular stomach. Furthermore, at $40^{\circ} \mathrm{C}$, the expression level was also higher in the leg muscle, followed by the lungs, pituitarium, kidneys, uropygial gland, ovaries, hypothalamus, cerebellum, liver, spleen, pectoral muscle, cerebrum, glandular stomach, muscular stomach, and heart. With the exception of the heart, the expression levels of HSP70 mRNA in tissue were significantly higher at $40^{\circ} \mathrm{C}$ than at $25^{\circ} \mathrm{C}$ (Table 6). 
Table 6. Differences in expression of $\mathrm{HSP} 70 \mathrm{mRNA}$ in FG tissues at $25^{\circ} \mathrm{C}$ and $40^{\circ} \mathrm{C}$.

\begin{tabular}{lccr}
\hline Tissue & $40^{\circ} \mathrm{C}(5)$ & $25^{\circ} \mathrm{C}(5)$ & $P$ value \\
\hline Liver & $1.73 \pm 0.20$ & $0.02 \pm 0.02$ & 0.0158 \\
Kidney & $3.79 \pm 0.38$ & $0.05 \pm 0.02$ & 0.0036 \\
Ovary & $3.42 \pm 0.87$ & $0.05 \pm 0.02$ & 0.0016 \\
Spleen & $1.49 \pm 0.55$ & $0.03 \pm 0.04$ & 0.0096 \\
Pituitarium & $4.59 \pm 6.21$ & $0.13 \pm 0.04$ & $<0.0001$ \\
Muscular stomach & $0.48 \pm 0.22$ & $0.02 \pm 0.01$ & 0.0013 \\
Glandular stomach & $0.81 \pm 0.87$ & $0.03 \pm 0.01$ & 0.0006 \\
Lung & $7.10 \pm 1.64$ & $0.27 \pm 0.23$ & 0.0365 \\
Uropygial gland & $3.72 \pm 1.34$ & $0.16 \pm 0.09$ & 0.0093 \\
Pectoral muscle & $1.24 \pm 1.30$ & $0.06 \pm 0.004$ & $<0.0001$ \\
Leg muscle & $10.07 \pm 1.87$ & $0.55 \pm 0.49$ & 0.0012 \\
Hypothalamus & $2.59 \pm 0.84$ & $0.18 \pm 0.09$ & 0.0204 \\
Cerebrum & $1.18 \pm 0.48$ & $0.08 \pm 0.05$ & 0.023 \\
Cerebellum & $2.50 \pm 0.29$ & $0.22 \pm 0.19$ & 0.0054 \\
Heart & $0.45 \pm 0.06$ & $0.18 \pm 0.10$ & 0.7935 \\
\hline Parentheses &
\end{tabular}

Parentheses indicate the number of individuals. Data are reported as means \pm SE.

At $25^{\circ} \mathrm{C}$, the expression levels of $H S P 70$ mRNA in the pectoral muscle and muscular stomach were significantly higher in MG than in FG (Figure 1).

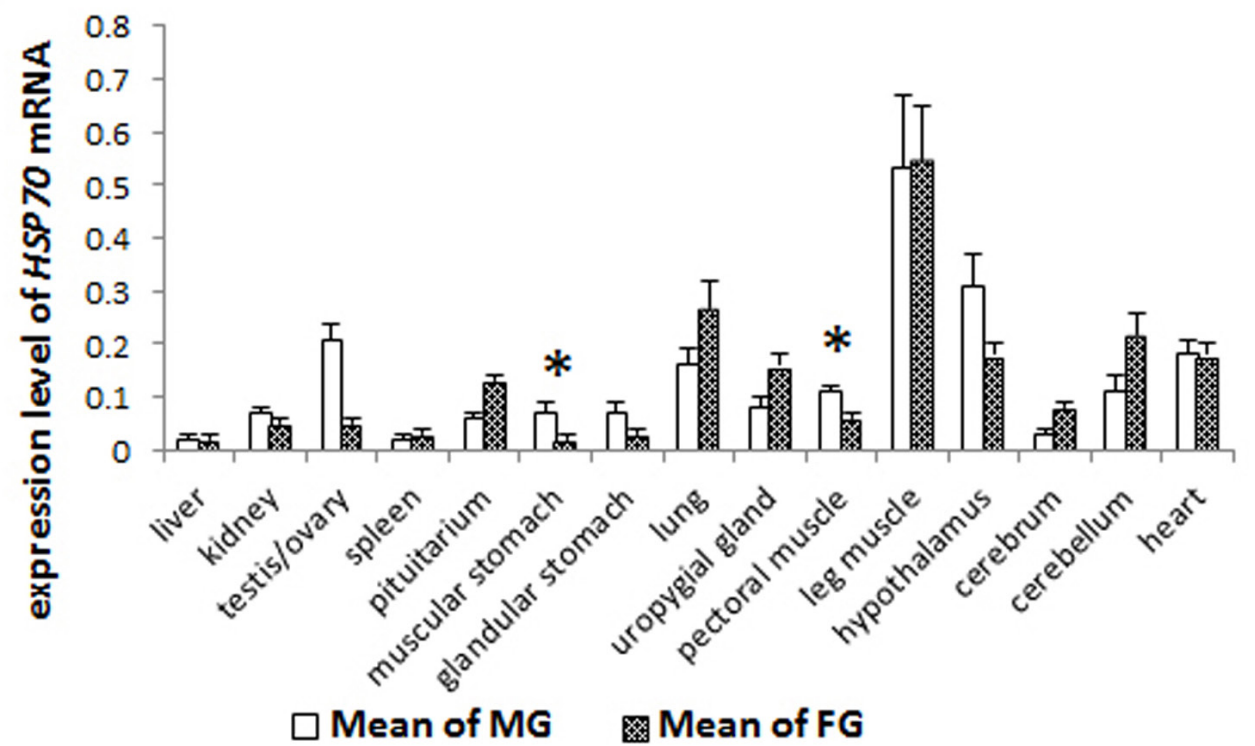

Figure 1. Tissue expression levels of goose $H S P 70 \mathrm{mRNA}$ at $25^{\circ} \mathrm{C}$. The $\mathrm{y}$-axis indicates the relative expression level of HSP70. MG, male goose; FG, female goose; *P $<0.05$.

At $40^{\circ} \mathrm{C}$, the expression levels of $H S P 70$ mRNA in all tissues except the leg muscle and cerebellum were significantly higher in MG than in FG (Figure 2). In contrast, the expression level of HSP70 mRNA in the leg muscle was significantly lower in MG than in FG. The expression level of HSP70 mRNA in the cerebellum did not differ significantly between MG and FG (Figure 2). 


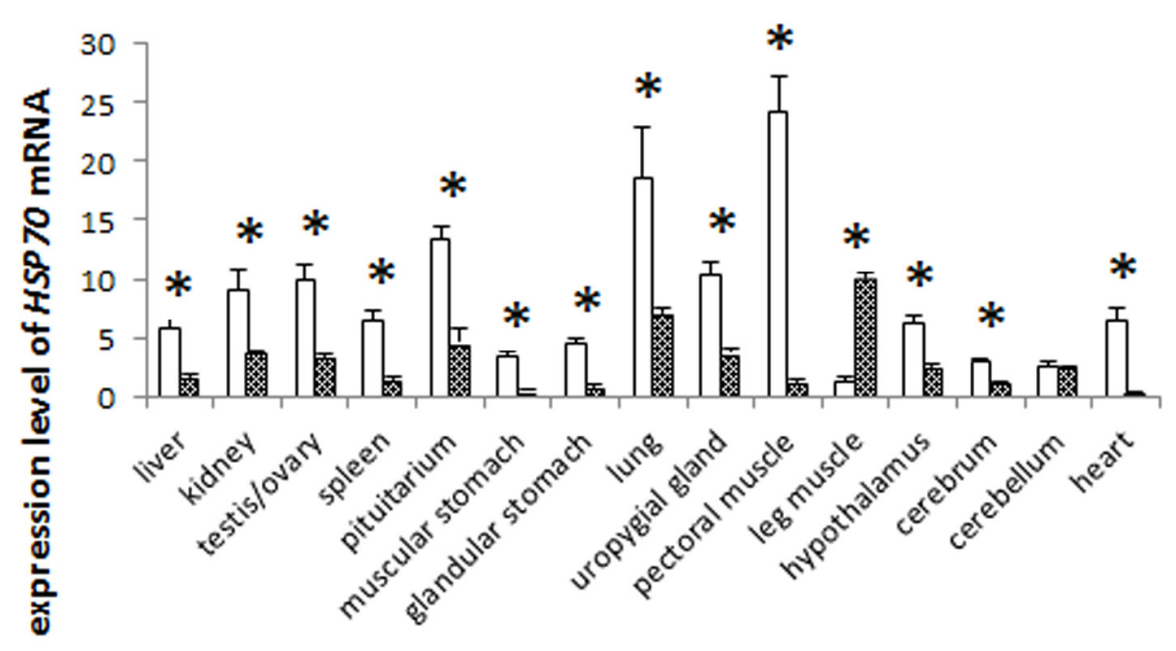

\section{$\square$ Mean of MG Mean of FG}

Figure 2. Tissue expression levels of goose $H S P 70$ mRNA at $40^{\circ} \mathrm{C}$. The $y$-axis indicates the relative expression level of HSP70. MG, male goose; FG, female goose; ${ }^{*} \mathrm{P}<0.05$.

\section{DISCUSSION}

The nucleotide sequence of avian HSP70 is known to be conserved. Gaviol et al. (2008) reported sequence homologies of Japanese quail and red jungle guinea fowl of 98 and $99 \%$ respectively. Hence, in the present study, we cloned goose HSP70 according to chicken HSP70 sequence. We showed that, similar to other avian species, goose HSP70 is intronless. This finding implies that $H S P 70$ is highly conserved. The gene structure may be associated with environmental adaptability.

We sequenced pooled DNA and identified 18 SNPs (one SNP per $106 \mathrm{bp}$ ) within the goose HSP70 ORF and 5'UTR. This polymorphism frequency was higher than that previously found in chicken HSP70. Previous studies in our laboratory identified 10 SNPs within the chicken HSP70 ORF. The SNP frequency was approximately one per $190 \mathrm{bp}$, which is consistent with the chicken genomic SNP frequency (Wong et al., 2004). However, most of the SNPs did not cause amino acid transformations. In the present study, we found three transformed amino acids among the 18 SNPs, possibly because of the different breeds of geese investigated.

Davis et al. (2008) considered that the low corticosterone level in quail plasma might improve stress resistance and inhibit the expression of HSP70. In the present study, SNP S3 of WZG was significantly associated with the serum corticosterone level at $25^{\circ} \mathrm{C}(P<0.05)$; moreover, TT had a lower serum corticosterone level than the other two genotypes. The serum corticosterone level for TT differed only slightly before and after heat stress, suggesting that the TT genotype exhibits higher heat stress resistance than the other two genotypes. In fowl, strains with low H/ Ls show improved heat stress resistance (Chen et al., 2013). SNP S11 of WZG was significantly associated with the $H / L(P<0.05)$; moreover, TC had a lower $H / L$ than the other two genotypes, implying that $\mathrm{S} 11$ is related to heat stress resistance.

Goose is a waterfowl species and therefore it may show relatively high sensitivity to heat stress. However, data regarding the mechanisms whereby heat stress affects waterfowl are lacking. 
In the present study, we applied acute heat stress and examined the expression level of HSP70 mRNA. We found that HSP70 was expressed in all tissues of the goose, and that the expression levels showed gender and tissue specificity. Maak et al. (2003) reported that chicken HSP70 expression was heat inducible. Zhen et al. (2006) reported heat-induced expression of chicken HSP70. These authors showed that under normal growth conditions, expression of HSP70 in the liver was significantly higher than that in muscle. In contrast, during acute heat stress, expression of HSP70 was higher in the brain than in the muscle. In our present study, we showed that the expression levels of $H S P 70$ mRNA in tissue except leg muscle were significantly higher at $40^{\circ} \mathrm{C}$ than at $25^{\circ} \mathrm{C}$, implying that expression of goose $H S P 70$ mRNA is induced by heat stimulation. After heat treatment, the expression levels of HSP70 mRNA in each tissue (except the leg muscle and cerebellum) were significantly higher in MG than in FG, indicating that FG may show higher thermal stress resistance than MG.

\title{
CONCLUSIONS
}

In the present study, we cloned goose HSP70 and showed that this gene contained a 1905-bp ORF and no introns. We found that goose $T+237 \mathrm{C}$ was significantly correlated with serum corticosterone level, whereas goose $\mathrm{T}+1122 \mathrm{C}$ was significantly correlated with $\mathrm{H} / \mathrm{L}$. The expression of goose $\mathrm{HSP} 70$ showed gender differences at $40^{\circ} \mathrm{C}$ but not at $25^{\circ} \mathrm{C}$; moreover, in general, expression was significantly higher at $40^{\circ} \mathrm{C}$ than at $25^{\circ} \mathrm{C}$. Taken together, our findings indicate that goose HSP70 plays an important role in severe heat stress.

\section{Conflicts of interest}

The authors declare no conflict of interest.

\section{ACKNOWLEDGMENTS}

\author{
Research supported by a Science and Technology Project of Guangdong Province \\ (\#2009B090300088).
}

\section{REFERENCES}

Ajloo D, Moosavi-Movahedi AA, Sadeghi M and Gharibi H (2002). Comparative structural and functional studies of avian and mammalian hemoglobins. Acta. Biochim. Pol. 49: 459-470.

Beckham JT, Wilmink GJ, Mackanos MA, Takahashi K, et al. (2008). Role of HSP70 in cellular thermotolerance. Lasers Surg. Med. 40: 704-715.

Chen CF, Bordas A, Gourichon D and Tixier-Boichard M (2004). Effect of high ambient temperature and naked neck genotype on performance of dwarf brown-egg layers selected for improved clutch length. Br. Poult. Sci. 45: 346-354.

Chen ZY, Gan JK, Xiao X, Jiang LY, et al. (2013). The association of SNPs in Hsp90ß gene 5' flanking region with thermo tolerance traits and tissue mRNA expression in two chicken breeds. Mol. Biol. Rep. 40: 5295-5306.

Christensen VL, Noble DO and Nestort KE (2000). Influence of selection for increased body weight, egg production, and shank width on the length of the incubation period of turkeys. Poult. Sci. 79: 613-618.

Davis KA, Schmidt JB, Doescher RM and Satterlee DG (2008). Fear responses of offspring from divergent quail stress response line hens treated with corticosterone during egg formation. Poult. Sci. 87: 1303-1313.

Gaviol HC, Gasparino E, Prioli AJ and Soares MA (2008). Genetic evaluation of the HSP70 protein in the Japanese quail (Coturnix japonica). Genet. Mol. Res. 7: 133-139.

Hendrick JP and Hartl FU (1993). Molecular chaperone functions of heat-shock proteins. Annu. Rev. Biochem. 62: $349-384$.

Lindquist S and Craig EA (1988). The heat-shock proteins. Annu. Rev. Genet. 22: 631-677. 
Maak S, Melesse A, Schmidt R, Schneider F, et al. (2003). Effect of long-term heat exposure on peripheral concentrations of heat shock protein 70 (HSP70) and hormones in laying hens with different genotypes. Br. Poult. Sci. 44: $133-138$.

Mahmoud KZ, Beck MM, Scheideler SE, Forman MF, et al. (1996). Acute high environmental temperature and calciumestrogen relationship in the hen. Poult. Sci. 75: 1555-1562.

Martin EA, Nolan JV, Nitsan Z and Farrell DJ (1998). Strategies to improve the nutritive value of rice bran in poultry diets. IV. Effects of addition of fish meal and a microbial phytase to duckling diets on bird performance and amino acid digestibility. Br. Poult. Sci. 39: 612-621.

Miyabara EH, Nascimento TL, Rodrigues DC, Moriscot AS, et al. (2012). Overexpression of inducible 70-kDa heat shock protein in mouse improves structural and functional recovery of skeletal muscles from atrophy. Pflugers Arch. 463: 733741.

Rosenkrans CJ, Banks A, Reiter S and Looper M (2010). Calving traits of crossbred Brahman cows are associated with heat shock protein 70 genetic polymorphisms. Anim. Reprod. Sci. 119: 178-182.

Wong GK, Liu B, Wang J, Zhang Y, et al. (2004). A genetic variation map for chicken with 2.8 million single-nucleotide polymorphisms. Nature 432: 717-722.

Zerjal T, Gourichon D, Rivet B and Bordas A (2013). Performance comparison of laying hens segregating for the frizzle gene under thermoneutral and high ambient temperatures. Poult. Sci. 92: 1474-1485.

Zhen FS, Du HL, Xu XP, Luo QB, et al. (2006). Tissue and allelic-specific expression of hsp70 gene in chickens: basal and heat-stress-induced mRNA level quantified with real-time reverse transcriptase polymerase chain reaction. Br. Poult. Sci. 47: 449-455. 